\title{
A new genus and new species of Staphylinidae (Coleoptera) from Baltic amber
}

\author{
GrZEGORZ PAŚNIK and DANIEL KUBISZ
}

\begin{abstract}
Institute of Systematics and Evolution of Animals, Polish Academy of Sciences, Slawkowska 17, 31-016 Kraków, Poland; e-mail: pasnik@isez.pan.krakow.pl,kubisz@isez.pan.krakow.pl
\end{abstract}

Key words. Coleoptera, Staphylinidae, Lathrobium, Sepedophilus, Palaeosepedophilus, Dictyon, Phymatura, Aleochara, new genus, new species, Baltic amber

\begin{abstract}
One new genus and nine new species of Staphylinidae are described from Baltic amber, namely Palaeosepedophilus gen.n. and the species P. succinicus sp.n., Lathrobium balticum sp.n., Lathrobium succini sp.n., Lathrobium ambricum sp.n., Lathrobium jantaricum sp.n., Sepedophilus balticus sp.n., Dictyon antiquus sp.n., Phymatura electrica sp.n., Aleochara baltica sp.n. Their affinity with related species is discussed.
\end{abstract}

\section{INTRODUCTION}

There are few staphylinid fossils described from amber. The first comprehensive description of Staphylinidae in Baltic amber was given by Gravenhorst (1806). Since then only five species of Staphylinidae have been described from Baltic amber: Bembicidiodes inaequicollis Schaufuss, 1889; Lathrobium (Palaeolobrathium) whitei Abdullah \& Abdullah, 1968; Pseudolesteua insinuans Schaufuss, 1890; Stenus (Parastenus) priscus Benick, 1943; Adinopsis groehni Zerche, 1999. Numerous species of staphylinids from amber, particularly Baltic amber, await description.

The following paper presents the description of one new genus and nine new species from amber of Tertiary age (35-55 million years). These finds increase the total number of staphylinids described from Baltic amber to fifteen species and eleven genera.

The following institutions kindly contributed material for this study. The abbreviations cited below for each institution are used in all text citations.

ISEA Institute of Systematics and Evolution of Animals, Polish Academy of Sciences, Kraków.

UG Department of Invertebrate Zoology, University of Gdańsk.

\section{MATERIAL AND METHODS}

For detailed viewing most pieces of amber were reshaped on a grindstone, then wet ground by hand to within about one $\mathrm{mm}$ of the fossil, using progressive grades of tungsten carbide paper, followed by polishing with cloth and leather impregnated with buffing rouge. Rectilinear facets were ground on three sides (dorsal, lateral, ventral) if possible. Oblique facets were sometimes ground in order to view the head, particularly on convex specimens. Observations were made using a Leica MZ 12.5 dissecting microscope, and high intensity incident light from a fiber optic illuminator. Much higher light levels are often required to view opaque fossils than is needed to view extant material. Measurements were made with an ocular micrometer.

\section{Subfamily Paederinae \\ Tribe Lathrobiini}

\section{Lathrobium succini sp. $\mathrm{n}$.}

(Figs 1-3)

Description. Length ca. $6.0 \mathrm{~mm}$. Body elongate (Figs 1-2), subparallel-sided, moderately convex; ground colour black, elytra pitchy brown, legs and antennae brown.

Head slightly transverse (Fig. 2), about 1.18 times wider than long, moderately depressed, as wide as pronotum; eyes moderately large, protruding beyond lateral contours of head, length of each seen from above about 1.5 times shorter than postocular region; temples slightly arcuate; punctation moderately coarse and moderately dense. Antennae elongate, extending beyond basal $2 / 3$ of pronotum, antennomere 1 robust and dilated apically, antennomere 2 elongate, about 2 times longer than wide, antennomere 3 more than 2 times longer than wide and longer than antennomere 2, antennomeres 4-11 moniliform, subequal in length.

Pronotum subquadrate (Fig. 2), about as wide as long, parallel-sided, only very slightly narrowed in straight line posteriorly; punctation coarse and moderately dense.

Elytra quadrate (Fig. 2), dilated posteriorly, at suture as long as pronotum at midline; punctation coarse and dense. Scutellum subtriangular, finely and sparsely punctured.

Abdomen subparallel-sided, slightly diverging toward apex, widest at level of tergite 6 ; punctation fine and dense. Lateral parts of tergite 8 curved up in lateral view (Fig. 3).

Type material. Holotype, female: No. 3232b (UG).

Affinity. Lathrobium succini sp.n. resembles extant species $L$. castaneipenne Kolenati, 1846, but it differs externally by its smaller size, the darker elytra, the larger and more protruding eyes and by the finer elytral punctation.

Etymology. The specific epithet "succini" is an adjective from the Latin noun "succinum", meaning amber.

\section{Lathrobium balticum sp.n.}

(Figs 4-5) 

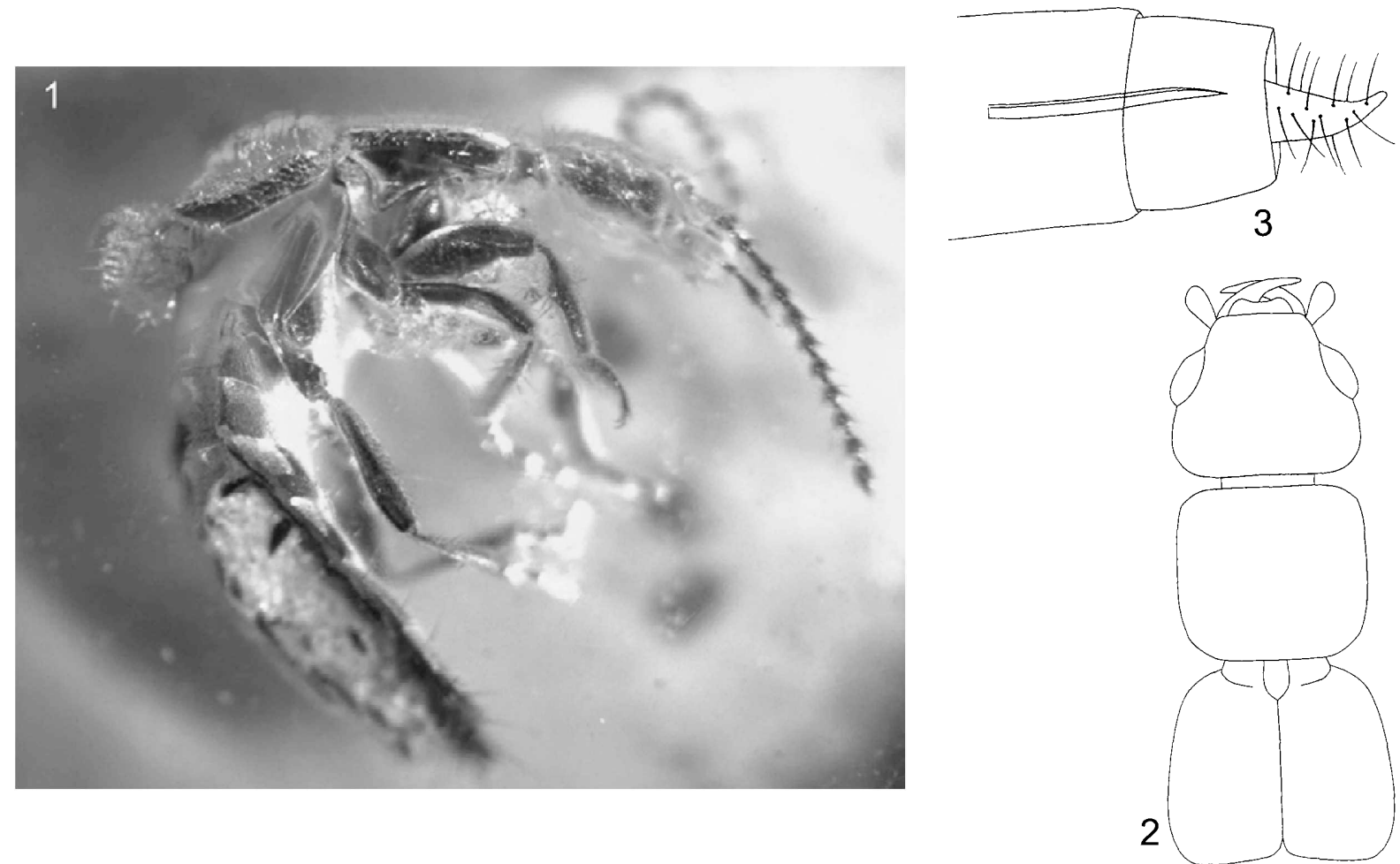

Figs 1-3: Lathrobium succini sp.n. 1 - habitus; 2 - shape of head, pronotum and elytra in dorsal view; 3 - apex of abdomen in lateral view.

Description. Length ca. $4.5 \mathrm{~mm}$. Body elongate (Figs 4-5), nearly subparallel-sided, moderately depressed; ground colour black, legs pitchy brown.

Head subquadrate (Fig. 5), slightly longer than wide, moderately convex; eyes small, moderately protruding beyond lateral contours of head, length of each seen from above about 1.5 times shorter than postocular region; temples parallel-sided, hind angles broadly rounded; punctation fine and dense. Antennae relatively long, extending to the base of pronotum, antennomere 1 robust and dilated apically, antennomeres 2 and 3 subequal in length, about 2 times longer than wide, antennomeres 4-11 about 1.5 times longer than wide.

Pronotum parallel-sided (Fig. 5), subquadrate, slightly longer than wide, as wide as head, widest in apical 1/3, lateral sides parallel-sided; punctation fine and moderately sparse.
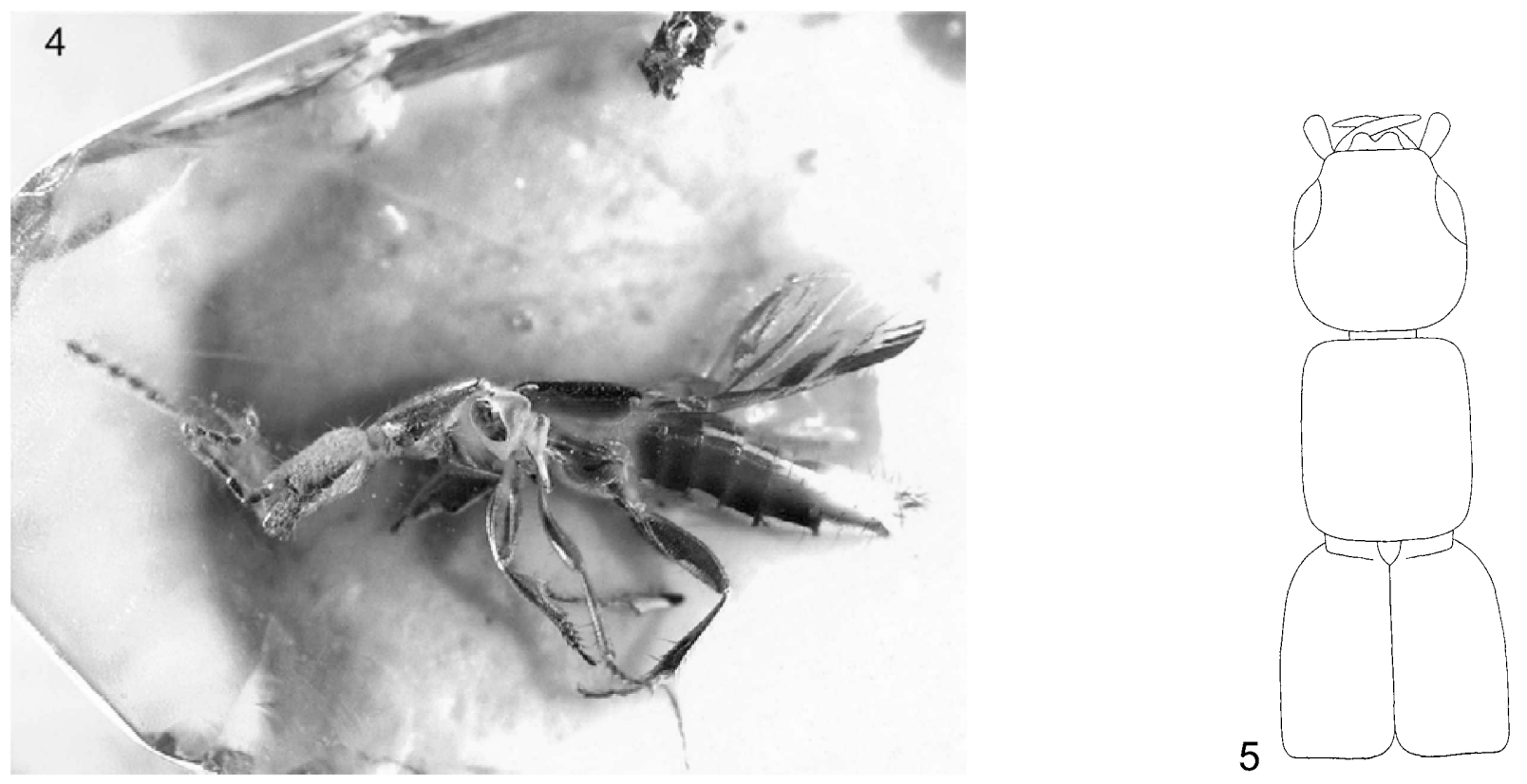

Figs 4-5: Lathrobium balticum sp.n. 4 - habitus; 5 - shape of head, pronotum and elytra in dorsal view. 

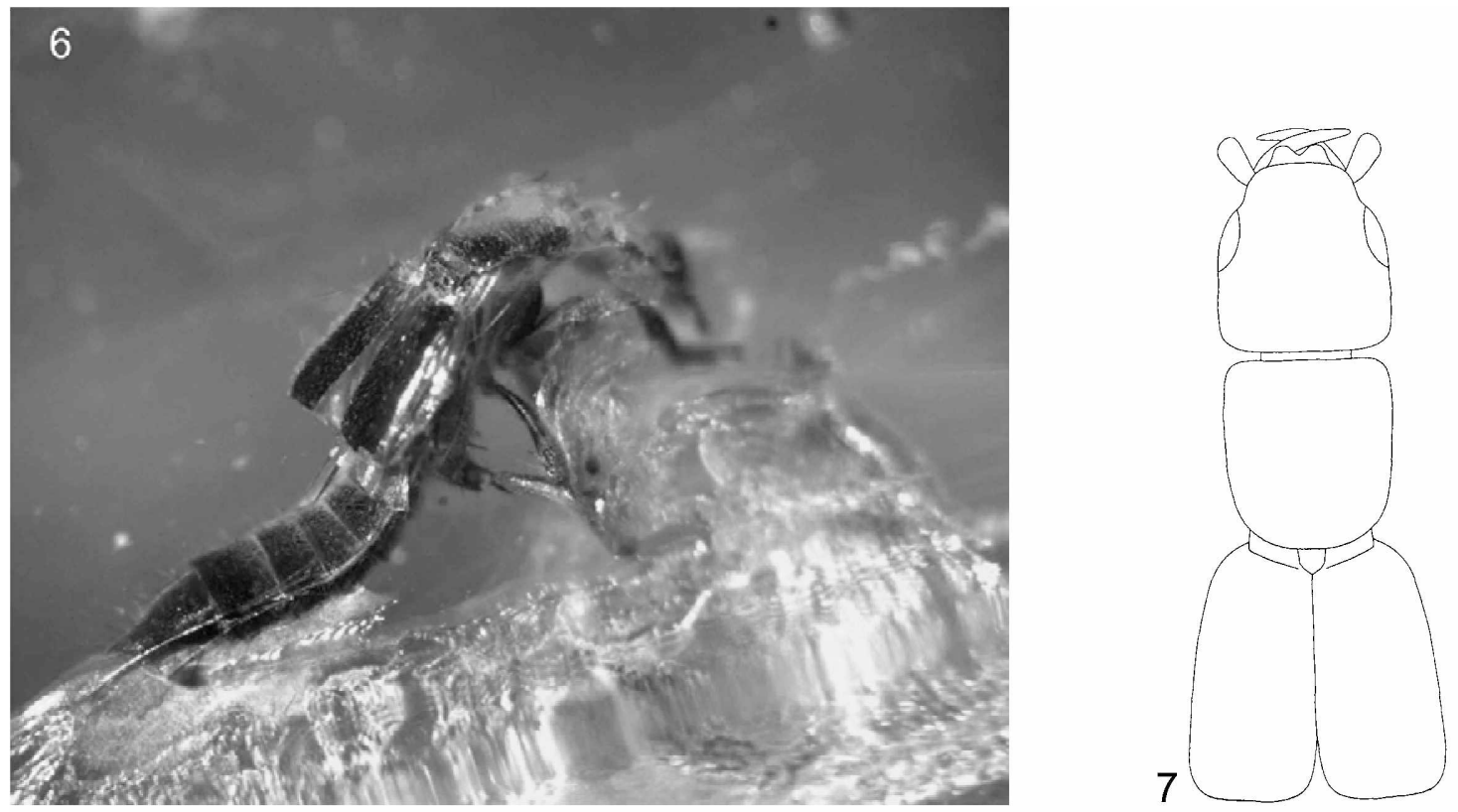

Figs 6-7: Lathrobium jantaricum sp.n. 6 - habitus; 7 - shape of head, pronotum and elytra in dorsal view.

Elytra quadrate (Fig. 5), slightly dilated posteriorly, at sides about as long as pronotum at midline; punctation fine and moderately dense. Scutellum subtriangular, finely and sparsely punctured. Abdomen subparallelsided, slightly diverging toward apex, widest at level of tergite 6 , punctation fine and very dense.

Type material. Holotype, female: No. 1/1529/187/00 (ISEA).

Affinity. Lathrobium balticum sp.n. is similar to the extant species L. pallidum Nordmann, 1837, but it can be distinguished from that species by its larger size, darker colour, shorter temples, and by the finer punctation on pronotum and elytra.

Etymology. "balticum" - from Baltic amber.

\section{Lathrobium jantaricum sp.n.}

(Figs 6-7)

Description. Length ca. $6.0 \mathrm{~mm}$. Body elongate (Figs 6-7), subparallel-sided, moderately depressed; ground colour black, elytra and legs pitchy brown, antennae black.

Head subquadrate (Fig. 7), slightly longer than wide, moderately depressed, slightly narrower than pronotum; eyes moderately large, slightly protruding beyond lateral contours of head, length of each seen from above about 1.5 times shorter than postocular region; temples parallelsided, hind angles rounded; punctation fine and moderately dense. Antennae elongate, extending to the base of pronotum, antennomere 1 robust and dilated apically, antennomeres 2 and 3 elongate, 2 times longer than wide, antennomeres 4-11 about 1.5 times longer than wide, spindle-shaped.

Pronotum quadrate (Fig. 7), about as wide as long, lateral sides narrowed in straight line to rounded hind angles; punctation moderately fine and moderately dense.

Elytra elongate (Fig. 7), moderately dilated posteriorly, at suture distinctly longer than pronotum at midline; punctation coarse and moderately dense. Scutellum subtriangular, finely and sparsely punctured.
Abdomen subparallel-sided, slightly diverging toward apex, widest at level of tergite 6; punctation fine and dense.

Type material. Holotype, female: No. 1161 (UG).

Affinity. Lathrobium jantaricum sp.n. is similar to L. balticum sp.n., but it differs externally from the mentioned species by shorter antennae, shorter pronotum with lateral sides more narrowed posteriorly, longer elytra and denser punctation on elytra.

Etymology. "Jantar" is an old Lithuanian name for amber.

\section{Lathrobium ambricum sp.n.}

(Figs 8-9)

Description. Length ca. $6.5 \mathrm{~mm}$. Body elongate (Figs 8-9), subparallel-sided, moderately depressed; ground colour black, legs and antennae dark brown.

Head quadrate (Fig. 9), nearly as long as wide, moderately depressed, as wide as pronotum; eyes moderately large, slightly protruding beyond lateral contours of head, length of each seen from above about 1.5 times shorter than postocular region; temples parallel-sided; punctation fine and moderately sparse. Antennae very long, extending beyond basal $1 / 3$ of elytra, antennomere 1 robust and dilated apically, antennomeres 2 and 3 elongate, subequal in length, about 2 times longer than wide, antennomeres 4-11 spindle-shaped.

Pronotum elongate (Fig. 9), about 1.3 times longer than wide, sides narrowed in straight line to rounded hind angles; punctation coarse and moderately dense.

Elytra nearly parallel-sided (Fig. 9), 1.3 times longer than wide, longer than pronotum at midline; punctation coarse and dense. Scutellum subtriangular, finely and sparsely punctured.

Abdomen subparallel-sided, slightly diverging toward apex, widest at level of tergite 6 ; punctation fine and dense.

Type material. Holotype, female: No. 1/1531/187/00 (ISEA). 

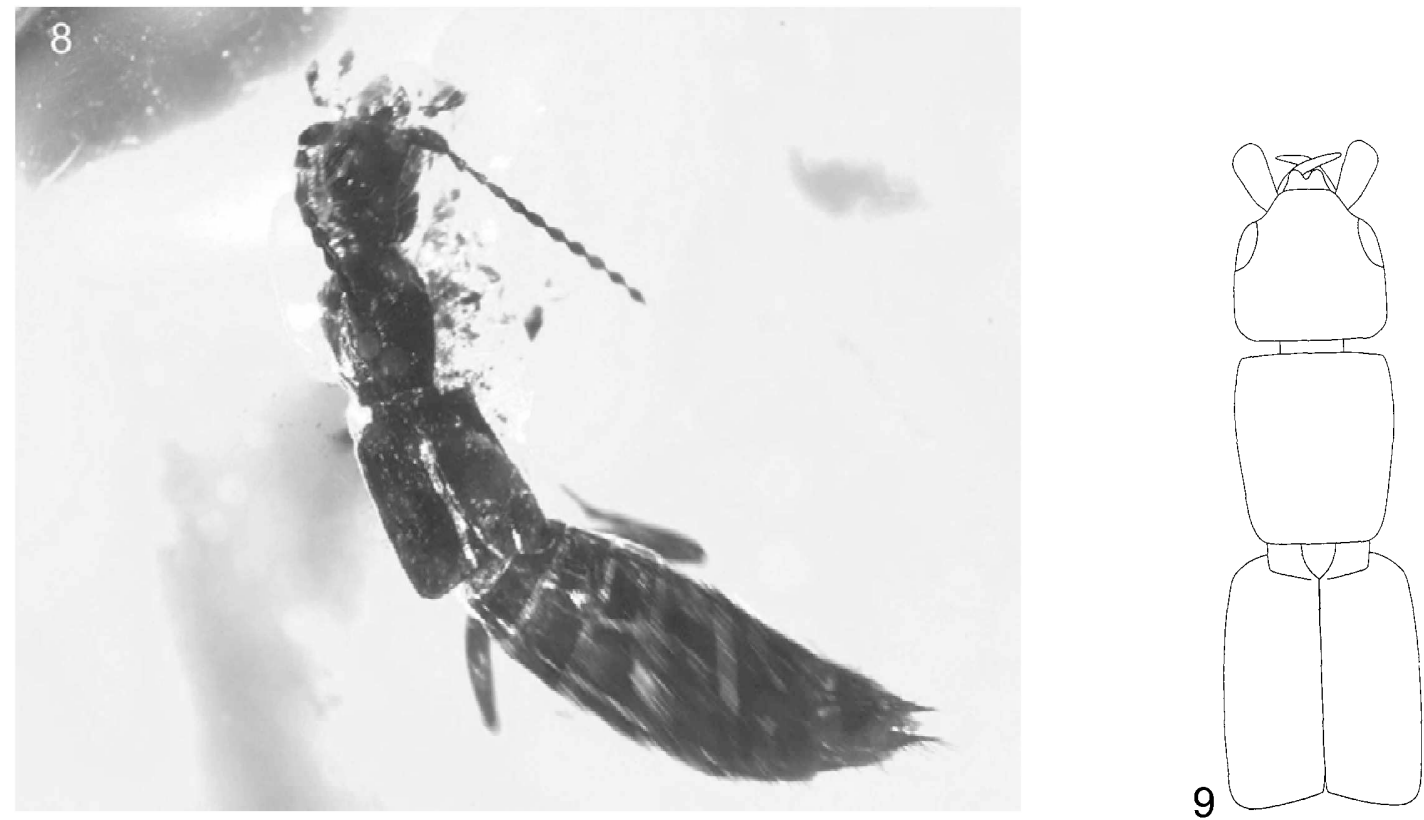

Figs 8-9: Lathrobium ambricum sp.n. 8 - habitus; 9 - shape of head, pronotum and elytra in dorsal view.

Affinity. Lathrobium ambricum sp.n. differs from the extant species of Lathrobium by the conspicuously thickened first antennal segment. In general appearance the new species is similar to $L$. jantaricum sp.n., from which it can be readily distinguished by the more transverse head, longer and more narrowed posteriorly pronotum and by the parallel-sided elytra.

Etymology. "ambricum" is an adjective derived from the English noun "amber".

\section{Subfamily Tachyporinae}

Tribe Tachyporini

Sepedophilus balticus sp.n.

(Figs 10-12)
Description. Length ca. $4.0 \mathrm{~mm}$. Body oval (Fig. 10), widest across pronotum near base; ground colour brown, posterior margins of abdominal tergites reddish, antennae brown with antennomeres 1-3 red, legs reddish-brown.

Head transverse, narrower than pronotum; eyes large, moderately protruding beyond lateral contours of head, temples short; surface of head with fine and moderately dense punctation, pubescence short and sparse. Antennae increase in width apically, antennomeres 1-3 elongate, antennomere 3 longer than 2, antennomere 4 quadrate, antennomeres 5-10 transverse, antennomere 10 about 1.5 times wider than long.
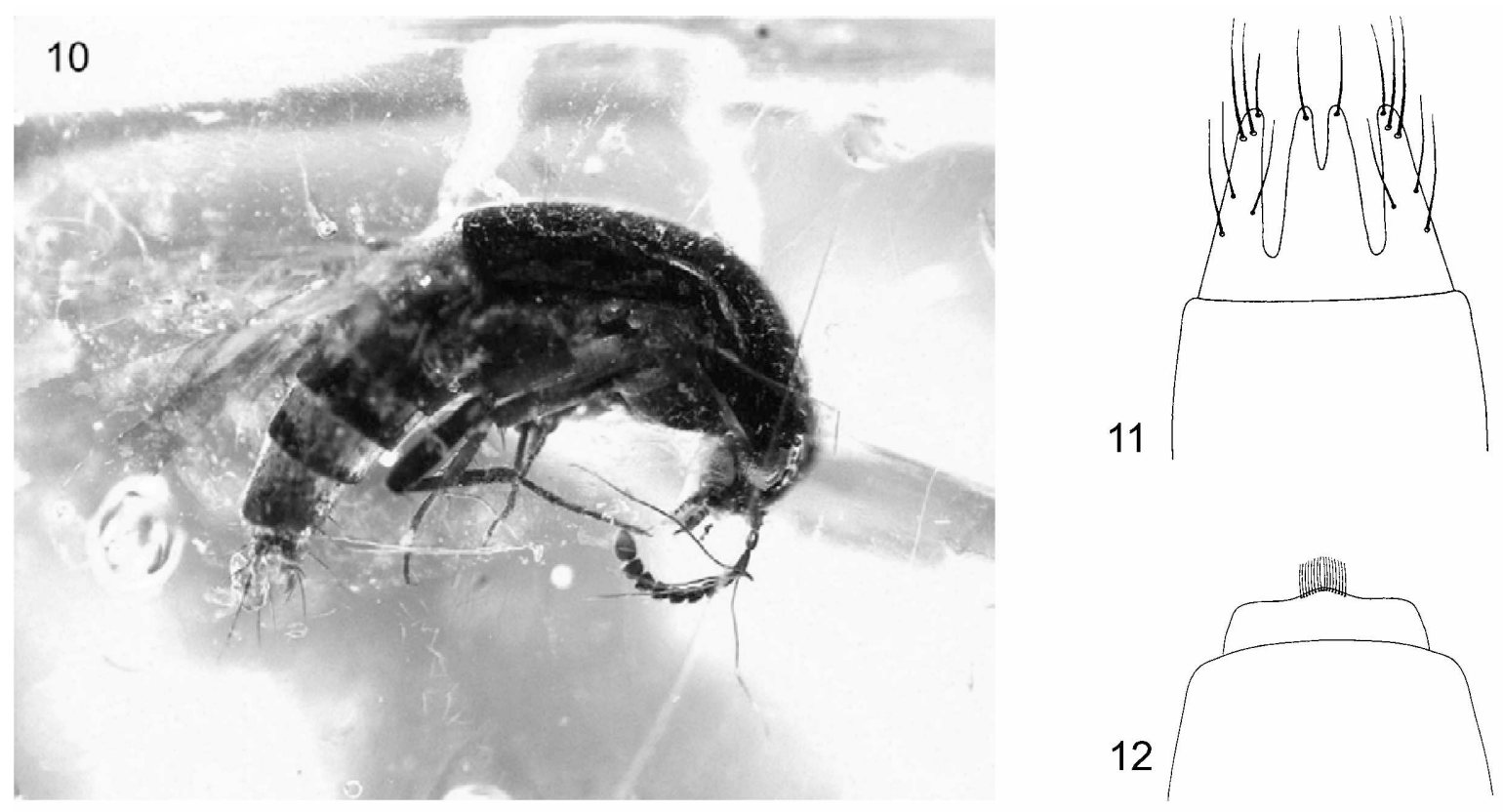

Figs 10-12: Sepedophilus balticus sp.n. 10 - habitus; 11 - female tergite $8 ; 12$ - female sternite 8 . 
Pronotum transverse and strongly convex, without lateral setae, widest near base, lateral sides arcuately narrowed to anterior margin, base slightly bisinuate, hind angles broadly rounded; punctation fine and moderately dense, pubescence fine, short and dense.

Elytra transverse, about as long as pronotum at midline, narrowed posteriorly; punctation fine and dense, pubescence short and moderately dense. Wings fully developed.

Abdomen acuminate to apex; punctation fine and dense, pubescence very short, fine and dense.

Female. Tergite 8 as in Fig. 11, sternite 8 as in Fig. 12.

Type material. Holotype, female: No. 1/1528/187/00 (ISEA)

Affinity. Sepedophilus balticus sp. n. resembles the extant species S. testaceus (Fabricius, 1792), but it differs from that species by the more protruding eyes, more transverse antennomeres $8-10$, less convex pronotum and by longer elytra.

Etymology. "balticus" from Baltic amber.

\section{Palaeosepedophilus gen. nov.}

Type species. Palaeosepedophilus succinicus sp.n. (Figs 13-20)

Description. Body broadly oval (Fig. 13), widest across base of pronotum, strongly convex, surface distinctly and relatively densely pubescent. Head transverse, inserted into pronotum to level of posterior margin of eyes. Antennae (Fig. 15) with 11 antennomeres, relatively long, extending beyond middle of pronotum. Labrum strongly transverse, anterior margin slightly emarginate. Maxillary palpi 4-segmented (Figs 14 and 16), segment 1 short, segment 2 moderately long, slightly dilated apically, segment 3 distinctly dilated apically, longer than segment 2 , segment 4 strongly compressed ventrodorsally, axe-shaped. Labial palpi 3-segmented (Fig. 17), segments 1 and 2 subequal in length, segment 3 very slender, much narrower and longer than segment 2. Pronotum strongly transverse, widest near base, sides arcuately narrowed to apex, without lateral setae. Mesosternum carinate along midline, metasternum short, without median carina. Legs with tarsal formula 5-5-5, moderately long; all tibiae with apical ctenidia; protibiae (Fig. 18) with few bristles apically along outer margin, protarsi as long as protibiae, moderately dilated, tarsomeres $1-4$ short, subequal in length, tarsomere 5 as long as tarsomeres 1-4 combined; meso- and metatarsi longer than tibiae. Elytra widest near base, distinctly narrowed posteriorly, sides without lateral setae. Abdomen strongly acuminate (Fig. 19), without paratergites, all sternites and tergites with long and strong bristles.

Affinity. The type species clearly represents a genus in the Tachyporini, very close to Sepedophilus Gistel, 1856 and Euconosoma Cameron, 1918. It differs from both genera as the protibiae lack rows of spines along the outer margin and in the compressed ventro-dorsally, axe-shaped last segment of its maxillary palpi.

\section{Palaeosepedophilus succinicus sp.n.}

(Figs 13-20)

Description. Length ca. $2.8 \mathrm{~mm}$. Body broadly oval (Fig. 13), widest across pronotum near base; ground colour pitchy brown, posterior margins of abdominal tergites reddish, antennae and legs brown.

Head transverse, narrower than pronotum; eyes large, slightly protruding beyond lateral contours of head, temples short; surface of head with fine and dense punctation, pubescence short and relatively sparse. Antennae short (Fig. 13 and 15), increase in width apically, antennomere 1 robust, dilated apically, antennomeres 2 and 3 elongate, subequal in length, antennomeres 4-7 about 1.5 times longer than wide, antennomeres 8-10 quadrate, antennomere 11 as long as two preceding antennomeres.

Pronotum transverse and strongly convex, without lateral setae, widest near base, lateral sides arcuately narrowed towards anterior margin, base truncate, hind angles broadly rounded; punctation fine and moderately dense, pubescence fine, short and dense.

Elytra quadrate, narrowed posteriorly, about as long as pronotum at midline; punctation fine and dense, pubescence fine and dense. Wings fully developed.

Abdomen acuminate towards apex (Fig. 19); punctation fine and dense, pubescence very short, fine and dense.

Male. Tergite 8 as in Fig. 20, sternite not visible.

Type material. Holotype, male: No. 3079 (UG).

Etymology. The specific epithet "succinicus" is an adjective from the Latin noun "succinum", meaning amber.

\section{Subfamily Aleocharinae \\ Tribe Mesoporini \\ Dictyon antiquus sp.n.}

(Figs 21-22)

Description. Length ca. $1.3 \mathrm{~mm}$. Body oval (Fig. 21), strongly convex; ground colour black, antennae and legs brown.

Head transverse, narrower than pronotum; eyes large, strongly protruding from lateral contours of head, length of each seen from above 3 times longer than postocular region; punctation fine and moderately sparse. Antennae short (Fig. 22), increase in width apically, antennomeres 1 and 2 robust, subequal in length, antennomere 3 elongate, about 2 times longer than wide, antennomeres 4-7 small, quadrate, antennomeres 8-11 transverse, abruptly wider than preceding antennomeres and forming loose club.

Pronotum transverse, strongly convex, widest near base, lateral sides arcuately narrowed towards apex, base slightly bisinuate, hind angles obtuse, pronotal epipleura not visible; punctation fine, dense and asperate, pubescence short and fine.

Elytra transverse, at sides about as long as pronotum at midline, at suture shorter than pronotum at midline, narrowed posteriorly, postero-lateral angles distinctly sinuate; punctation fine, very dense and asperate, pubescence short and fine.

Abdomen acuminate towards apex, tergite 7 longer than two preceding segments combined; punctation fine, very dense and slightly asperate.

Type material. Holotype, female: No. 1968 (UG).

Affinity. Dictyon antiquus sp.n. is closely related to the extant species Dictyon pumilio Eppelsheim (1886) from Transcaucasus, but it can be distinguished from that species by its 

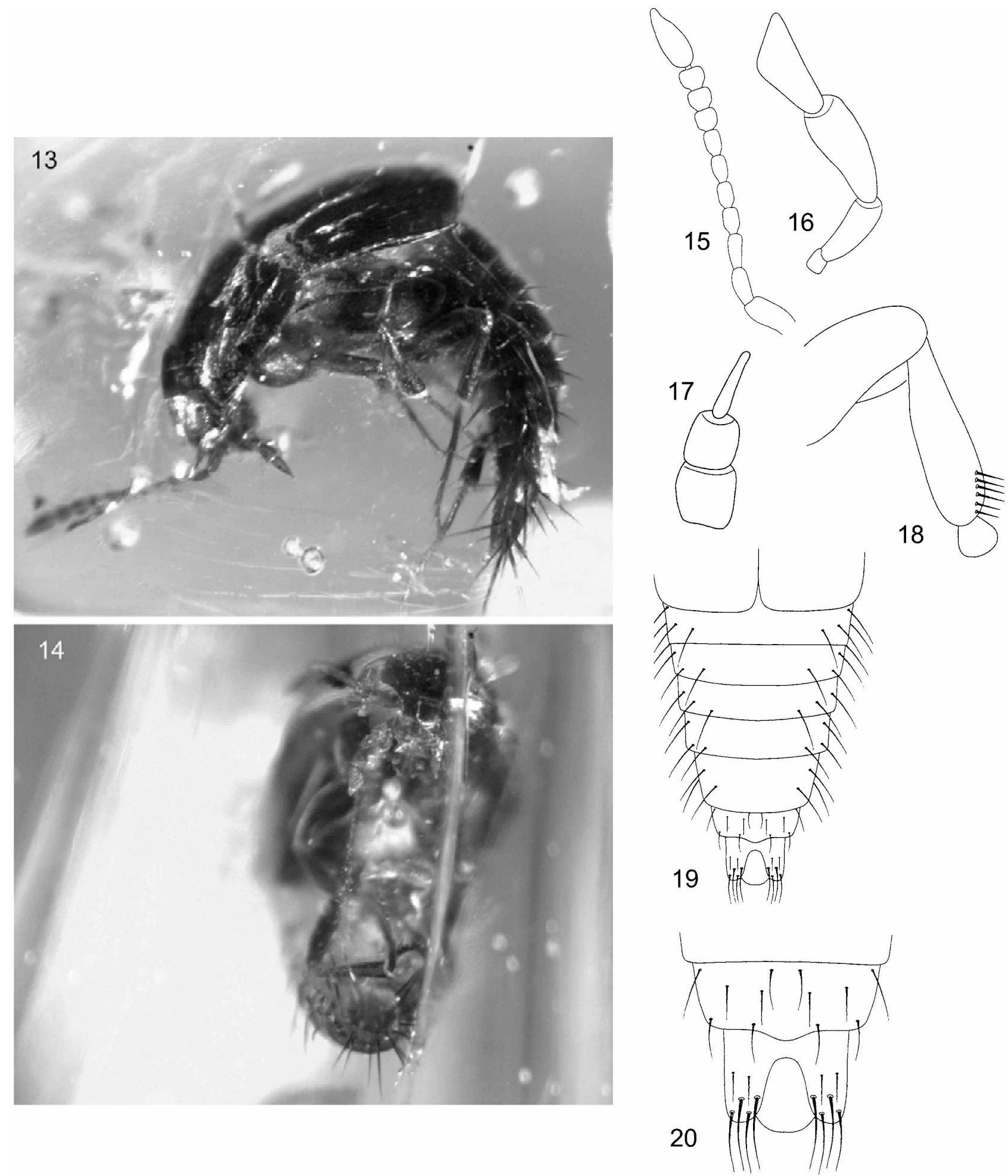

Figs 13-20: Palaeosepedophilus succinicus sp.n. 13 - habitus in lateral view; 14 - habitus in ventral view; 15 - antenna; 16 maxillary palpus; 17 - labial palpus; 18 - protibia; 19 - shape of abdomen; 20 - male tergites 7-8.

smaller size, darker colouration, more transverse antennomeres 4-7 and by coarser and denser punctation of the body.

Etymology. The name of the new species is the Latin word "antiquus" - meaning old, ancient.
Tribe Bolitocharini

\section{Phymatura electrica sp.n.}

(Figs 23-24)

Description. Length ca. $2.0 \mathrm{~mm}$. Body parallel-sided (Fig. 24), moderately flattened, slightly shining; ground colour brownish-red, antennae and legs yellowish-red. 


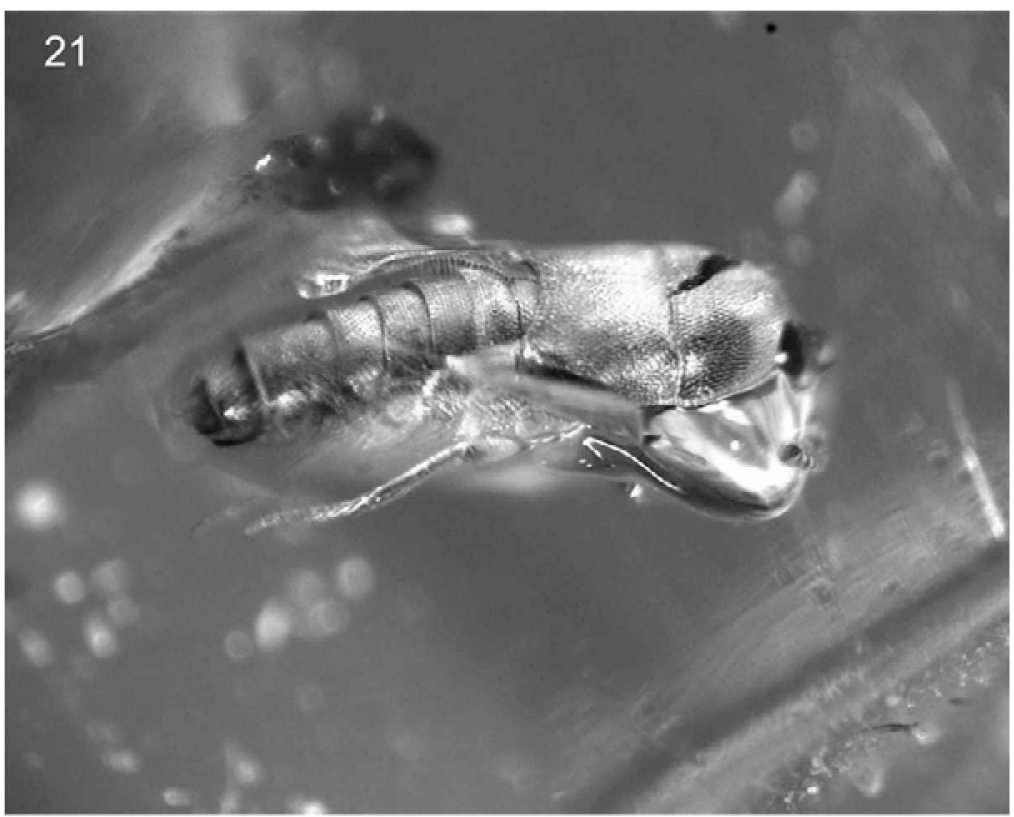

22

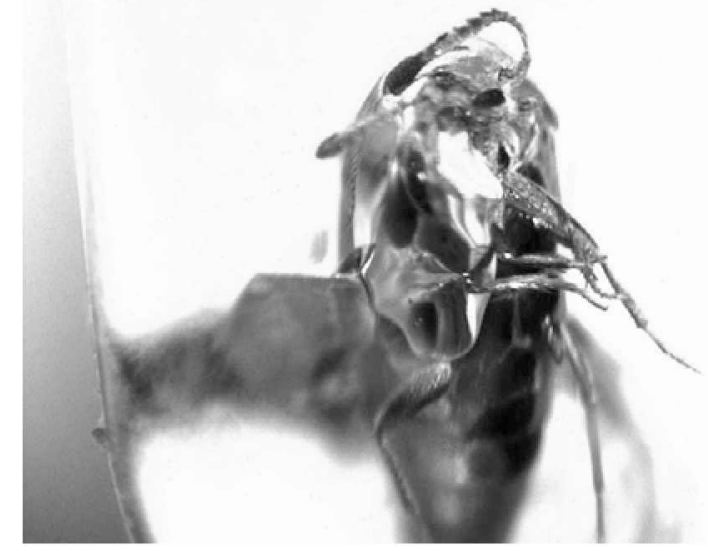

Figs 21-22: Dictyon antiquus sp.n. 21 - habitus in lateral view; 22 - habitus in ventral view.

Head quadrate, as long as wide, widest across eyes; eyes large, strongly protruding beyond lateral contours of head, length of each seen from above about 2 times longer than postocular region; temples parallel-sided, hind angles rounded; surface of head with round- meshed microsculpture, punctation fine and moderately dense. Antennae short (Figs 23-24), increase in width apically, antennomere 3 shorter than 2, antennomeres 4-10 transverse, antennomere 10 about 1.5 times wider than long, antennomere 11 conical, as long as two preceding antennomeres combined.

Pronotum transverse, 1.5 times wider than long, widest in front of middle, lateral sides slightly arcuately narrowed towards obtuse hind angles; base slightly bisinuate, pronotal epipleura not visible; microsculpture roundmeshed, punctation fine, dense and asperate.
Elytra transverse, about 1.7 times wider than their length at sides, at suture slightly longer than pronotum at midline; punctation moderately coarse, dense and asperate.

Abdomen parallel-sided, bases of tergites $3-5$ each with transverse impression, punctation fine and moderately dense, diminishing on tergites 7 and 8. Tarsal formula 4-4-5.

Type material. Holotype, female: No. 296 (UG).

Affinity. The new species should be assigned to the genus Phymatura on the basis of diagnostic characters, especially the tarsal formula (4-4-5), transverse pronotum with not visible epipleura, large eyes, basal segment of metatarsus subequal in length to following two tarsal segments combined. In general appearance the new species is similar to the extant species $P$. brevicollis (Kraatz, 1856), but differs by its smaller size, the 

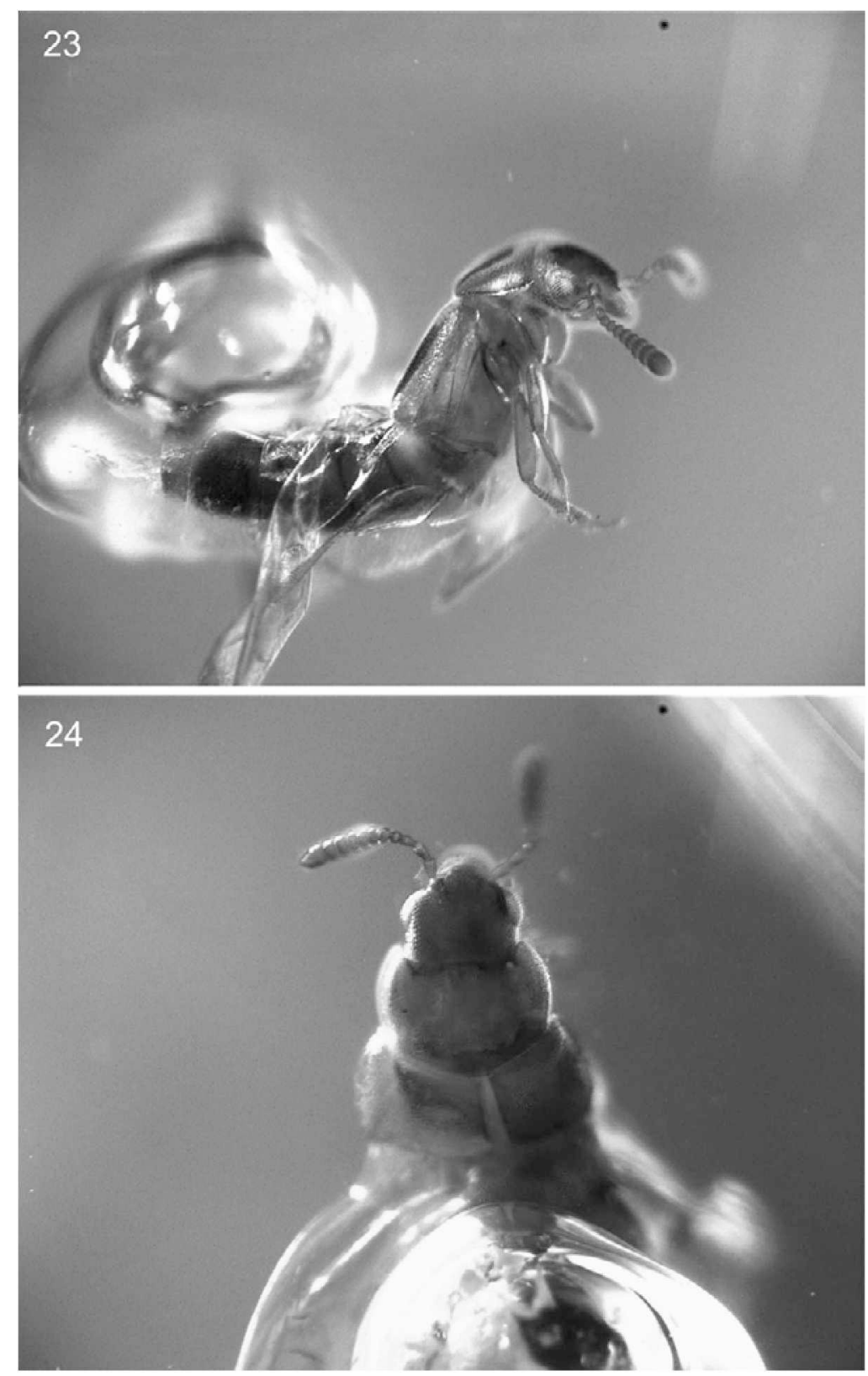

Figs 23-24: Phymatura electrica sp.n. 23 - habitus in lateral view; 24 - habitus in dorsal view.

lighter colouration, the finer punctation of head and pronotum and by the shorter antennae.

Etymology. "electrica" - an old Greek name for amber.

\section{Tribe Aleocharini}

Aleochara (s.str.) baltica sp.n.

(Figs 25-26)

Description. Length ca. $2.0 \mathrm{~mm}$. Body robust (Fig. 25), parallel-sided, moderately convex; ground colour brown, legs red, antennae black with antennomeres 1-3 red.

Head transverse, narrower than pronotum, widest across eyes; eyes large, strongly protruding beyond lateral contours of head, length of each seen from above about 3 times longer than postocular region. Antennae short (Fig. 26), increase in width apically, antennomere 3 shorter than 2, antennomeres 4-10 transverse, antennomere 10 about 2 times wider than long, antennomere 11 conical, as long as two preceding together.

Pronotum transverse, convex, as wide as elytra, widest in posterior $1 / 3$, lateral sides arcuate, more strongly narrowed towards apex than base; punctation moderately coarse and moderately dense.

Elytra transverse, about 1.3 times wider than long, at sides about as long as pronotum at midline, slightly dilated posteriorly; punctation moderately fine, moderately dense and asperate.

Abdomen parallel-sided, bases of tergites 3-5 each with fine transverse impression; punctation fine, dense and slightly asperate.

Type material. Holotype, 1 specimen (sex unknown): No. 1/1530/187/00 (ISEA). 

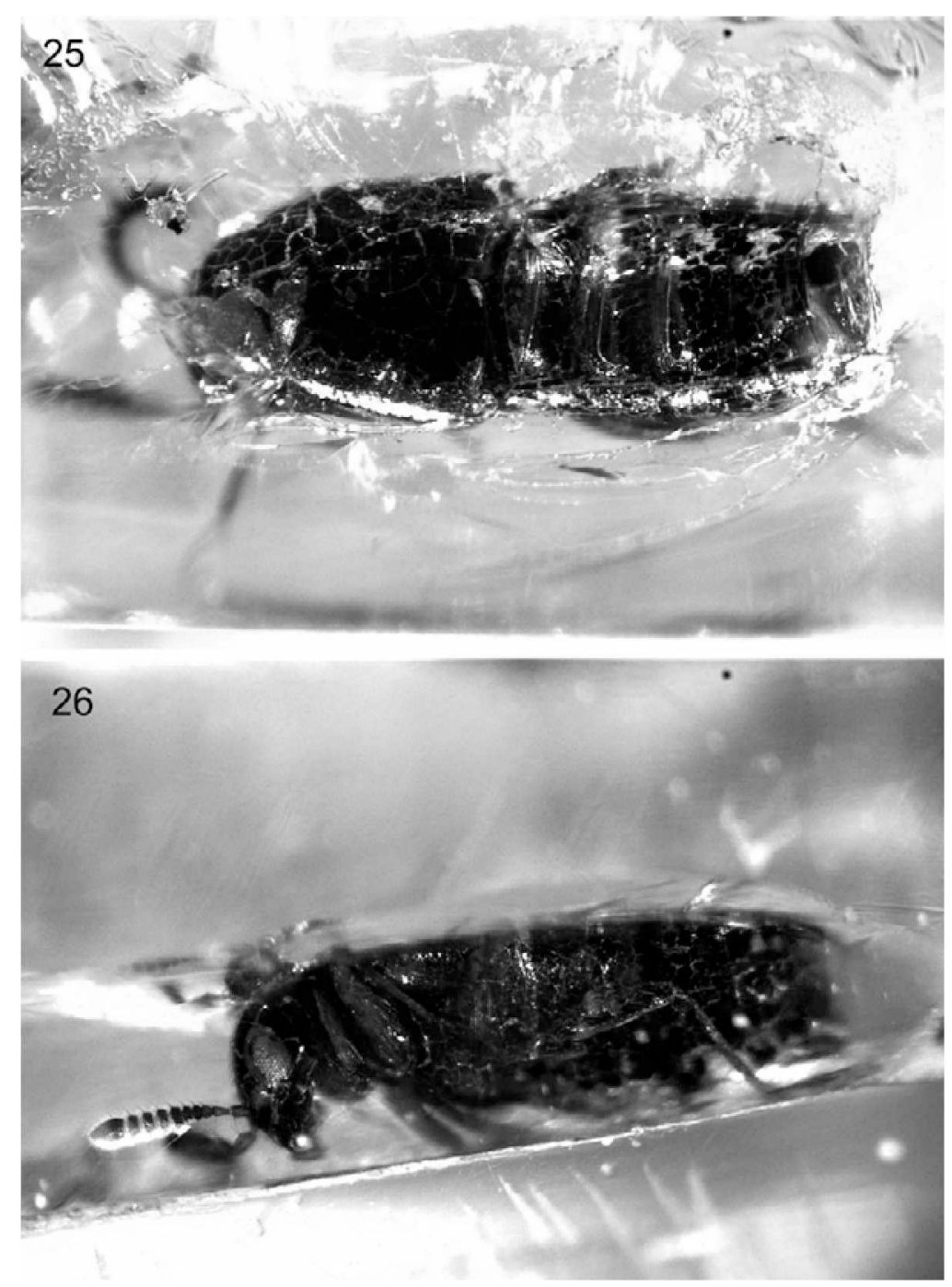

Figs 25-26: Aleochara baltica sp.n. 25 - habitus in dorsal view; 26 - habitus in lateral view.

Affinity. The new species should be assigned to the genus Aleochara on the basis of diagnostic characters, especially the maxillary palpi with 5 palpomeres. Externally, Aleochara baltica sp.n. resembles the extant species $A$. moesta Gravenhorst, 1802 , but it may be readily distinguished from that species by its smaller size, darker elytra, coarser pronotal punctation and by finer elytral punctation.

Etymology. "baltica" - from Baltic amber.

ACKNOWLEDGEMENTS. We would like to express our sincere thanks to Mrs Elżbieta Sontag (Gdańsk) for lending a valuable material for this study.

\section{REFERENCES}

Abdullah M. \& Abdullah A. 1968: The discovery and probable phylogenetic significance of Lathrobium (Palaeolobrathium) whitei, a new subgenus and species of Paederinae (Col: : Staphylinidae) from Baltic amber. Entomol. Mon. Mag. 104: 1-3.

BeNICK L. 1943: Ein Stenus aus dem baltischen Bernstein: St. (Parastenus) priscus n.sp. (Coleoptera: Staphylinidae). Arb. Morphol. Taxon. Entomol. 10: 101-104.

Cameron M. 1918: New Oriental Staphylinidae. Entomol. Mon. Mag. 60: 214-219.
Eppelsheim E. 1886: Diagnosen neuer Staphyliniden aus dem Caucasus und aus Lenkoran. Verh. Naturf. Ver. Brünn 22: 11-16.

FABRICIUS J.C. 1792: Entomologia systematica emendata et aucta, secundum classes, ordines, genera, species, adjectis synonymis, locis, observationibus, descriptionibus. Vol. 1. Hafniae, 348 pp.

Gistel J. 1856: Die Mysterien der Europäischen Insectenwelt; ein Geheimer Schüssel für Sammler aller Insecten-Ordungen und Stände. T. Dannheimer, Kempten, 530 pp.

Gravenhorst J.L.C: 1806. Monographia Coleopterorum Micropterorum. Gottingen, $248 \mathrm{pp}$.

MärKeL F. 1844: Beiträge zur Kenntniss der unter Ameisen lebenden Insekten. Zweites Stiuck. Z. Entomol. Germar, Leipzig 5: 193-271.

Nordmann A. 1837: Symbolae ad Monographiam Staphyliniorum. Acad.Caesareae Scientiarum, Petropoli, $167 \mathrm{pp}$.

Schaufuss L.W. 1889: Einige Käfer aus dem baltischen Bernsteine. Berliner Entomol. Zeitsch. 32: 266-270.

Schaufuss L.W. 1890: Eine Staphylinengattung aus dem baltischen Bernsteine. Entomol. Nachr. 16: 69-70.

ZERCHE L. 1999: Eine neue Art der Gattung Adinopsis Cameron aus dem Baltischen Bernstein. Beitr. Entomol. 49: 97-105.

Received October 13, 2000; revised October 17, 2001; accepted December 12, 2001 